\title{
Pre-service Science Teachers' Knowledge, Practices and Behaviors about Organ Donation and Transplantation
}

\author{
Eylem Eroğlu Doğan ${ }^{1, *} \&$ Doğan Doğan ${ }^{1}$ \\ ${ }^{1}$ Faculty of Education, Abant İzzet Baysal University, 14280 Bolu, Turkey \\ *Correspondence: Faculty of Education, Abant İzzet Baysal University, 14280 Bolu, Turkey. \\ Tel: 90-374-254-1000. E-mail: edogan@ibu.edu.tr
}

Received: August 20, 2015 Accepted: September 4, 2015 Published: September 15, 2015

doi:10.5296/ije.v7i3.8183 URL: http://dx.doi.org/10.5296/ije.v7i3.8183

\begin{abstract}
There is a clear need that every individual in a society should be well informed about the organ donation and transplantation issue to contribute to the efforts to increase low donation rates. Science teachers have a crucial role in increasing young pupils' knowledge and awareness of organ donation by providing them with the necessary scientific information. Therefore, the present research examined the knowledge, practices and behaviors of pre-service science teachers regarding organ donation and transplantation, to help them to be better prepared science teachers. A total of 265 participants from two universities in Turkey responded to an organ donation and transplantation questionnaire. Descriptive statistics, $\mathrm{t}$-test and chi-square test were used in the data analyses. While $92.8 \%$ of participants supported organ donation regardless of their year of study, only $1.1 \%$ declared that they were registered to be a donor. Pre-service science teachers in this study showed generally a low level of knowledge regardless of their year of study and gender. Despite having a low level of knowledge regarding organ donation and transplantation, they were generally willing to donate their own organs. These findings raised questions about the extent to which pre-service science teachers have the necessary knowledge, practices and behaviors to support student learning when they become real teachers. The implications of these findings for science teacher education in Turkey was also addressed.
\end{abstract}

Keywords: Organ donation, Knowledge, Behavior, Pre-service teacher, Science education 


\section{Introduction}

Organ transplantation is the replacement of a non-functioning organ with a healthy organ surgically removed from a living donor or a cadaver in order to improve the health of a very ill or dying person (Savaser, Sahiner, Dogan, Caglar, \& Mutlu, 2015). The demand for organ donation and transplantation is rapidly increasing in many countries all over the world and in Turkey owing to the increasing incidence of end-stage failure of many vital organs, while the supply of organs from donors remains limited to meet the increasing demand (Abouna, 2008; Goodarzi et al., 2015; Tarhan, Dalar, Yildirimoglu, Sayar, \& Altin, 2014). As a result, the number of people on transplant waiting lists and the wait time for receiving an organ is also rising rapidly. While donated organs, which are blind to race, religion, age, and gender can help save or represent a hope for life to thousands (Türkyilmaz et al., 2013), hundreds of people die each year due to the lack of transplantable organs.

Although the world population shares this common problem, and each person may possibly be both a potential recipient and a potential donor, many people are unwilling to donate their own organs (Etheredge, Turner, \& Kahn, 2014). The fear that doctors will declare death prematurely to procure one's organs, and the belief that organ donation is against one's religion are mentioned to be the two dominant reasons for an unwillingness to donate organs (Morgan, Harrison, Afifi, Long, \& Stephenson, 2008). Other reasons often cited include a lack of knowledge about organ donation (Alashek, Ehtuish, Elhabashi, Emberish, \& Mishra, 2009), desire for body integrity preservation (Jung, 2013), relatives' views on donation, and the type of organ involved in donation (Sperling \& Gurman, 2012). Thus, the procurement of organs remains a major problem despite the significant advances in organ transplantation. This reveals the importance and urgency on the training about donation in order to increase the level of knowledge about donation and willingness to donate.

Research suggest that donation rates can be increased by planning and implementing appropriate educational interventions. For example, Radunz et al. (2012) conducted an educational intervention study concerning organ donation among medical students to increase willingness to donate organs, and reported that $42 \%$ of the students rated their attitude towards organ donation to be influenced positively after the intervention. Savaser et al. (2015) analyzed the outcomes a nursing education regarding organ donation, and pointed out that nursing education positively affected the opinion of the students and changed their attitudes about organ donation. McGlade and Pierscionek (2013) analyzed the attitudes, behavior and knowledge of student nurses about organ donation based on a pre-test post-test study, and found that various aspects of organ donation knowledge of participants were effectively improved and their ability to discuss organ donation intentions with their family was positively influenced. Cardenas, Thornton, Wong, Spigner and Allen (2010) analyzed the impact of a school-based health education intervention on organ donation and transplantation, and reported that students in the intervention group demonstrated a significant increase in knowledge scores, as well as positive movement of opinion regarding willingness to donate that occurred independently of ethnicity, gender, and personal experience.

It is clear that starting from a young age, every individual in a society should be well 
informed about the organ donation and transplantation process to contribute to the efforts to increase low donation rates. This may be achieved through an innovative primary science curriculum that helps to increase the awareness of organ donation. In case of Turkey, several primary science education curriculum reforms that involve substantial breaks with the past science curricula were carried out under the leadership of the Ministry of National Education (MoNE), and with the collaboration of teachers and academicians during the last sixteen years (Elmas, Öztürk, Irmak, \& Cobern, 2014; MoNE, 2004; MoNE, 2005; MoNE, 2013). The most recent primary science curriculum, developed in 2013, incorporated a lesson about organ donation and transplantation under the "Living Things and Life Unit" for the 7th grade students in order to have them understand the importance of this process in terms of social solidarity (MoNE, 2013). The general goal was equipping every student to be scientifically literate citizens about this issue regardless of their individual differences. On the other hand, for successfully implementing the curriculum, it is also necessary that pre-service science teachers gain an adequate knowledge and demonstrate desired behaviors related to this process. Because when they become science teachers, they will teach not only the science content to their students but also affect their attitudes and behaviors about the subject.

To be a primary school science teacher in Turkey, candidates need to complete a four-year program which includes general science and laboratory courses; more specific science courses, such as genetics and biotechnology; mathematics courses; general culture and language courses; general education courses, such as educational psychology; science methods courses and some elective courses (Çakır, İrez, \& Doğan, 2010; see THEC, 2006). However, although organ donation and transplantation process is included in the latest primary school science curriculum (MoNE, 2013) and every science teacher has to teach this subject, Turkish pre-service science teachers do not take any regular course about this subject during their undergraduate education. Therefore, there is a clear need to reveal the current knowledge, practices and behaviors of pre-service science teachers about organ donation and transplantation to help them to be better prepared teachers (Simon, Chitpin, \& Yahya, 2010). Beside this, no research has been found on pre-service science teachers' knowledge, practices and behaviors about this process in the available literature.

The objective of this study was to examine the knowledge, practices and behaviors about organ donation and transplantation among Turkish pre-service science teachers in order to provide feedback to curriculum designers to make necessary changes in the national science teacher education curriculum. In this respect, the results of this study will contribute to the curriculum development studies in Turkey, and the advancement of the current literature about organ donation and transplantation process.

\section{Methodology}

\subsection{Participants}

Participants of this descriptive study were 207 female and 58 male pre-service primary science teachers enrolled in the first and final year of their teacher education program at two 
universities in Turkey. Purposeful sampling was employed to identify the participants (Johnson \& Christensen, 2013). This sample was chosen because the curricula, structure, and experiences in pre-service primary science teacher education are standard across Turkish faculties of education.

\subsection{Data Collection and Analysis}

The participants completed a questionnaire about organ donation and transplantation based on the previous validated frameworks (Marqués-Lespier, Ortiz-Vega, Sánchez, Soto-Avilés, \& Torres, 2013; Trompeta, Chen, Cooper, Ascher, \& Kools, 2010). The questionnaire consisted of a total of 18-item statements divided into three parts: The first part elicited socio-demographic variables (3-item). The second part questioned about the respondents' practices and behaviors related to organ donation (5-item). The final part investigated general knowledge about organ donation and transplantation (10-item), with questions posed in which the answer is either true or false. Score of 1 was assigned to correct answer and a value of 0 to incorrect answer. Total scores ranged from 0 to 10 ; higher scores reflects better knowledge about organ donation and transplantation. The Cronbach's alpha coefficient was found to be 0.82 , reflecting an acceptable internal consistency reliability (Nunnally \& Bernstein, 1994).

Before the administration of the questionnaire, the participants were briefed about the purpose of the study and they signed an informed consent form voluntarily. To ensure the respondent anonymity, consent forms were not collected. Then, the questionnaire forms were administered. Following the anonymous completion, the forms were collected for the data analysis. Only completed questionnaires were considered for the statistical analysis. Descriptive statistics were used to assess the demographic information; frequencies, percentages and averages were determined. Categorical variables were compared using chi-square test, and the means of continuous variables were compared using Student's $t$-test. All statistical analyses were performed using the Statistical Package for the Social Sciences database (SPSS, Version 17), and a level of 0.05 was considered to indicate statistical significance.

\section{Results}

\subsection{Characteristics of Study Participants}

Table 1 shows the demographic characteristics of the participants by their year of study. Among all the participants, 58 (21.9\%) were males and 207 (78.1\%) were females, the mean age of first-year and fourth-year of participants were 19.8 \pm 1.1 years $( \pm \mathrm{SD})$ and $23.1 \pm 1.3$ respectively. The overall average age was $21.6 \pm 1.2$ years. Of all the participants, $26.4 \%$ were from low-income families and $9.8 \%$ were from high-income families, whereas majority of them $(63.8 \%)$ were from middle-income families. 
Table 1. Demographic characteristics of participants by year of study

\begin{tabular}{lccc}
\hline & $\begin{array}{c}\text { First-Year } \\
(\mathrm{n}=133)\end{array}$ & $\begin{array}{c}\text { Fourth-year } \\
(\mathrm{n}=132)\end{array}$ & $\begin{array}{c}\text { Total } \\
(\mathrm{n}=265)\end{array}$ \\
\hline $\begin{array}{l}\text { Mean age (SD), year } \\
\text { Gender, n (\%) }\end{array}$ & $19.8(1.1)$ & $23.1(1.3)$ & $21.6(1.2)$ \\
$\quad$ Male & $28(21.1)$ & $30(22.7)$ & $58(21.9)$ \\
$\quad$ Female & $105(78.9)$ & $102(77.3)$ & $207(78.1)$ \\
Monthly family income (MFI), n (\%) & & & \\
$\quad$ Low & $34(25.6)$ & $36(27.3)$ & $70(26.4)$ \\
$\quad$ Middle & $85(63.9)$ & $84(63.6)$ & $169(63.8)$ \\
$\quad$ High & $14(10.5)$ & $12(9.1)$ & $26(9.8)$ \\
\hline
\end{tabular}

\subsection{Practices and behavior related to organ donation and transplantation}

Table 2 displays the results about the practices and behavior of participants related to organ donation by their year of study.

Table 2. Practices and behavior of participants related to organ donation by year of study

\begin{tabular}{|c|c|c|c|}
\hline & $\begin{array}{l}\text { First-Year } \\
(\mathrm{n}=133)\end{array}$ & $\begin{array}{l}\text { Fourth-year } \\
\qquad(n=132)\end{array}$ & $\begin{array}{c}\text { Total } \\
(\mathrm{n}=265)\end{array}$ \\
\hline \multicolumn{4}{|c|}{ Support organ donation } \\
\hline Yes & $124(93.2)$ & $122(92.4)$ & $246(92.8)$ \\
\hline No & $9(6.8)$ & $10(7.6)$ & $19(28.3)$ \\
\hline \multicolumn{4}{|c|}{ Registered to be organ donor, $\mathrm{n}(\%)$} \\
\hline Yes & $1(0.8)$ & $2(1.5)$ & $3(1.1)$ \\
\hline No & $132(99.2)$ & $130(98.5)$ & $262(98.9)$ \\
\hline \multicolumn{4}{|c|}{ Willingness to donate one's own organs, $n(\%)^{*}$} \\
\hline Yes & $104(78.2)$ & $86(65.2)$ & $190(71.7)$ \\
\hline No & $29(21.8)$ & $46(34.8)$ & $75(28.3)$ \\
\hline \multicolumn{4}{|c|}{ Knowing where to register to be organ donor, $\mathrm{n}(\%)^{*}$} \\
\hline Know & $62(46.6)$ & $82(62.1)$ & $144(54.3)$ \\
\hline Don't know & $71(53.4)$ & $50(37.9)$ & $121(45.7)$ \\
\hline \multicolumn{4}{|c|}{$\begin{array}{l}\text { Knowing the laws that control organ donation and } \\
\text { transplantation, } \mathrm{n}(\%)\end{array}$} \\
\hline Know & $36(27.0)$ & $34(25.8)$ & $70(26.4)$ \\
\hline Don't know & 97 (72.9) & 98 (74.2) & 195 (73.6) \\
\hline
\end{tabular}

$* p<.05$ compared between first-year and fourth-year participants. 
Although vast majorities of first-year (93.2\%) and fourth-year (92.4\%) pre-service science teachers believed in organ donation that it was a necessity for humanity, only $1(0.8 \%)$ and 2 $(1.5 \%)$ participants were registered respectively to be organ donors. There were no significant differences between both groups with regard to support organ donation or register to be an organ donor. However, out of 265 participants, 190 (71.7\%) expressed a willingness to become donors, and among them first-year pre-service science teachers were significantly more willing $(78.2 \%)(\mathrm{p}<.05)$ to donate their own organs than fourth-year pre-service science teachers $(65.2 \%)$.

When asked about knowing the laws that control organ donation and transplantation in Turkey, about a quarter of the entire population (26.4\%) indicated that they know the right answer, and no significant differences were detected for the law scores between these two groups. On the other hand, there was statistically significant difference $(\mathrm{p}<.05)$ between both groups in terms of knowing where to register to be organ donor, and that difference was in favor of the fourth-year group. While eighty-two (62.1\%) fourth-years marked "I know" option for this statement, only sixty-two (46.6\%) first-years chose the same option. Overall, one hundred forty-four $(54.3 \%)$ participant stated that they knew where to register to be an organ donor.

\subsection{Knowledge Regarding Donation and Transplantation}

Comparison of the results of knowledge scores about organ donation and transplantation among participants by their year of study are given in Table 3. It was found that fourth-year pre-service teachers differed significantly from their first-year counterparts in some knowledge aspects. A significantly higher percentage of fourth-year participants $(53.0 \%)$ knew that high blood pressure and diabetes were common causes for people to require a kidney transplant than those first-year participants $(33.8 \%)(\mathrm{p}<.05)$. Besides this, majority of the fourth-year participants $(74.2 \%)$ knew that a brain-dead person cannot recover and live, whereas around half of the first-year participants (56.4\%) could answer the same statement correctly, and there was statistically significant difference between each group $(\mathrm{p}<.05)$.

One of the most striking result of the study was that only 11.4 percent of the fourth-year and 12.0 of the first-year respondents thought that an ordinary working person has a better chance of getting an organ transplant as a rich person. Moreover, only $16.7 \%$ of the fourth-year respondents understood that there is no age limit for organ donation, compared to $17.3 \%$ of the first-year respondents. Pre-service teachers had also trouble with understanding that the family has the last word regarding donation once a patient declared brain dead, and only $25.6 \%$ of the first-years and $24.2 \%$ of the fourth-years were able to answer this statement correctly. They were also less knowledgeable about who will need to take anti-rejection drugs after a transplantation operation for the rest of his/her life. Moreover, the first-years had a mean score of $4.2 \pm 1.2( \pm \mathrm{SD})$ and fourth-years a mean of $4.5 \pm 1.1$ in terms of their level of knowledge about organ donation and transplantation. Overall, the study demonstrated that there was no significant difference between the mean of knowledge of the first-year and fourth-year participants ( $>$ >.05), and that they had insufficient level of knowledge regardless of their year of study. 
Table 3. Knowledge of participants about organ donation and transplantation by year of study

\begin{tabular}{|c|c|c|}
\hline \multirow[t]{2}{*}{ Statements } & $\begin{array}{l}\text { First-Year } \\
(\mathrm{n}=133)\end{array}$ & $\begin{array}{l}\text { Fourth-year } \\
(\mathrm{n}=132)\end{array}$ \\
\hline & \multicolumn{2}{|c|}{ Answered correctly, n (\%) } \\
\hline 1. A patient can receive an organ transplant from a living donor. & $90(67.8)$ & $93(70.4)$ \\
\hline $\begin{array}{l}\text { 2. After a transplant, the recipient will need to take anti-rejection } \\
\text { drugs for the rest of his/her life. }\end{array}$ & $48(36.1)$ & $43(32.6)$ \\
\hline $\begin{array}{l}\text { 3. Organ donors cannot have funerals because the body is } \\
\text { deformed by the removal of organs. }\end{array}$ & $66(49.6)$ & $61(46.2)$ \\
\hline $\begin{array}{l}\text { 4. Transplant recipients can live more than } 10 \text { years after a } \\
\text { transplant operation. }\end{array}$ & $120(90.2)$ & $117(88.6)$ \\
\hline $\begin{array}{l}\text { 5. High blood pressure and diabetes are common causes for } \\
\text { people to require a kidney transplant.* }\end{array}$ & $45(33.8)$ & $70(53.0)$ \\
\hline $\begin{array}{l}\text { 6. A rich person has a better chance of getting an organ transplant } \\
\text { than an ordinary working person. }\end{array}$ & $16(12.0)$ & $15(11.4)$ \\
\hline 7. It is possible for a brain-dead person to recover and live.* & $75(56.4)$ & $98(74.2)$ \\
\hline 8. The age of organ donors can range from 28 days to 70 years. & $23(17.3)$ & $22(16.7)$ \\
\hline $\begin{array}{l}\text { 9. If a deceased patient has signed an organ-donor card but the } \\
\text { family does not wish to donate the organ(s), the hospital is } \\
\text { required to honor the wishes of the family. }\end{array}$ & $34(25.6)$ & $32(24.2)$ \\
\hline $\begin{array}{l}\text { 10. After a transplant, the donor will need to take anti-rejection } \\
\text { drugs for the rest of his/her life. }\end{array}$ & $39(29.3)$ & $43(32.6)$ \\
\hline
\end{tabular}

${ }^{*} \mathrm{p}<.05$ compared between first-year and fourth-year participants.

When knowledge of participants regarding organ donation and transplantation compared with respect to the gender, more results that are significant obtained as shown in Table 4. There were significant differences between the levels of knowledge of male and female pre-service science teachers in terms of different knowledge aspects. Such as receiving an organ transplant from a living donor, survival years after a transplant operation, common causes of kidney transplantation, priority of wishes of the family over a signed donor card, and need not to take anti-rejection drugs for a donor after a transplantation operation $(p<.05)$. For example, sixty-eight (32.9\%) female participants answered that donors do not need to take immunosuppressive drugs, whereas only 14 (24.1\%) male participants answered the same statement correctly. Furthermore, one hundred fifty eight $(76.3 \%)$ female participants were aware that patients can receive organ transplant from living donors, and $93.7 \%$ knew that transplant recipients can live more than 10 years after a transplant operation. In contrast, only $43.1 \%$ and $74.1 \%$ of male participants correctly answered the above statements respectively. Consequently, a statistical significant result was obtained between the mean knowledge of female $(4.6 \pm 1.1)$ and male $(3.5 \pm 1.3)$ participants $(p<.05)$, indicating that males had a lower level of knowledge than females. 
Table 4. Knowledge of participants about organ donation and transplantation by gender

\begin{tabular}{|c|c|c|}
\hline \multirow[t]{2}{*}{ Statements } & $\begin{array}{l}\text { Female } \\
(\mathrm{n}=207)\end{array}$ & $\begin{array}{c}\text { Male } \\
(\mathrm{n}=58)\end{array}$ \\
\hline & \multicolumn{2}{|c|}{ Answered correctly, $\mathrm{n}(\%)$} \\
\hline $\begin{array}{l}\text { 1. A patient can receive an organ transplant from a living } \\
\text { donor.* }\end{array}$ & $158(76.3)$ & $25(43.1)$ \\
\hline $\begin{array}{l}\text { 2. After a transplant, the recipient will need to take } \\
\text { anti-rejection drugs for the rest of his/her life. }\end{array}$ & $72(34.7)$ & $19(32.7)$ \\
\hline $\begin{array}{l}\text { 3. Organ donors cannot have funerals because the body is } \\
\text { deformed by the removal of organs. }\end{array}$ & $100(48.3)$ & $27(46.6)$ \\
\hline $\begin{array}{l}\text { 4. Transplant recipients can live more than } 10 \text { years after a } \\
\text { transplant operation.* }\end{array}$ & $194(93.7)$ & $43(74.1)$ \\
\hline $\begin{array}{l}\text { 5. High blood pressure and diabetes are common causes for } \\
\text { people to require a kidney transplant.* }\end{array}$ & $101(48.8)$ & $14(60.6)$ \\
\hline $\begin{array}{l}\text { 6. A rich person has a better chance of getting an organ } \\
\text { transplant than an ordinary working person. }\end{array}$ & $25(12.1)$ & $6(10.3)$ \\
\hline 7. It is possible for a brain-dead person to recover and live. & $137(66.2)$ & $36(62.1)$ \\
\hline 8. The age of organ donors can range from 28 days to 70 years. & $35(16.9)$ & $10(17.2)$ \\
\hline $\begin{array}{l}\text { 9. If a deceased patient has signed an organ-donor card but the } \\
\text { family does not wish to donate the organ(s), the hospital is } \\
\text { required to honor the wishes of the family.* }\end{array}$ & $58(28.0)$ & $8(13.8)$ \\
\hline $\begin{array}{l}\text { 10. After a transplant, the donor will need to take anti-rejection } \\
\text { drugs for the rest of his/her life.* }\end{array}$ & $68(32.9)$ & $14(24.1)$ \\
\hline
\end{tabular}

${ }^{*} \mathrm{p}<.05$ compared between female and male participants.

The first and fourth-year participants had differed significantly in terms of their knowledge about the statement that "It is possible for a brain-dead person to recover and live", and the difference was in favor of fourth-years (Table 3). However, no statistical difference was found between the knowledge of male and female participants regarding this statement (Table 4). Similarly, when the results were compared by gender and year of study, very small proportions of participants correctly answered that there is no age limit for organ donation, and that a rich person has not a better chance of getting an organ transplant than an ordinary working person. In summary, these findings showed that participants lack of the relevant knowledge regarding organ donation and transplantation process. 


\section{Discussion}

The purpose of this study was to examine the knowledge, practices and behaviors regarding organ donation and transplantation of 265 pre-service science teachers in Turkey. An adapted instrument was used to measure the pre-service science teachers' knowledge, practices and behaviors related to this subject. Descriptive analysis of the demographic data showed that most of the participants were from low and middle-income families, and majority of them were females, which suggested a positive relationship between gender and choosing teaching as a career. This result is consistent with the previous studies that have demonstrated that teaching is becoming an increasingly female-dominated profession (Azman, 2013; Balyer \& Özcan, 2014; Low, Lim, Ch'ng, \& Goh, 2011).

This study presents significant results about the knowledge, practices and behaviors of pre-service teachers regarding organ donation and transplantation, which can be interpreted in terms of their formal and informal education practices. Pre-service science teachers receives a four-year formal science teacher education in sixty-seven faculties of education in Turkey (ÖSYM, 2015). Those science teachers candidates do not take any compulsory or even an elective course about organ donation and transplantation during their teacher education (see THEC, 2006). However, they may possibly gain a limited amount of information about this subject during their general biology or genetics and biotechnology courses. Therefore, it can be assumed that formal teacher training at the primary science teacher education programs of faculties of education in Turkey does not significantly affect the amount of knowledge gained by the pre-service teachers. On the other hand, there are different informal knowledge sources that may have profound effect on the amount of acquired knowledge and behaviors about this subject such as internet, television, radio, newspapers, announcements or posters, health professionals, relatives, friends, and some other sources. For instance, Katsari, Domeyer, Sarafis and Souliotis (2015) reported that educational level of parents and information from announcements or posters were important predictors of the knowledge, attitude and information regarding organ donation. In a similar study, the most important information sources were determined as visual media, followed by environment, friends and books (Köse, Önsüz, \& Topuzoğlu, 2015). However, media do not always broadcast scientific information about organ donation and transplantation. Therefore, it has been proposed that the organ donation authorities and organizations should engage in close relationships with media to prevent broadcasting of non-scientific information (Berrin \& Demirelli, 2008).

Participants in this study displayed an overwhelm support for organ donation (92.8\%) regardless of their year of study. However, when it comes to register to be an organ donor, only $1.1 \%$ of them responded that they were registered to be an organ donor. Personal beliefs, attitudes, and lack of relevant knowledge concerning donation and transplantation procedures might have negatively affected their decisions. Those results were consistent with previous research that has shown that differences exist between the attitudes and the actions of people in the organ donation issue (Chen et al., 2006; Doğan, Toprak, Sunal, \& Doğan, 2012; Perenc, Radochonski, \& Radochonski, 2012). Conversely, despite having relatively a low level of knowledge regarding organ donation and transplantation, first-year pre-service teachers were significantly more willing to donate their own organs than their fourth-year counterparts were. 
This result differs from some studies relating increased level of knowledge regarding donation with increased willingness to donate (Schaeffner, Windisch, Freidel, Breitenfeldt, \& Winkelmayer, 2004; Thornton et al., 2006). The reason for this diversity may be that the first-year pre-service teachers were more open to the idea of organ donation and were not confused with informal communications surrounding their decision making processes.

With respect to the year of study, participants generally showed low levels of knowledge about organ donation and transplantation, and there were significant differences between the first-years and fourth-years in some knowledge aspects. For instance, first-years had difficulties in understanding that a brain-dead person cannot recover and live. Another concept about which first-years were not aware was that high blood pressure and diabetes are common causes for people to require a kidney transplant. Collectively, these results imply that first-year pre-service teachers might not as much interested in organ donation and transplantation process. Not taking as many courses as their fourth-year counterparts might be another reason for their low level of knowledge. On the other hand, vast majority of participants in both groups were not aware that an ordinary working person has a better chance of getting an organ transplant as a rich person. This may be due to the general thought in our country that a rich person has all the financial advantages to get what he or she wants. Participants also failed to know that there is no age limit for the donation. Finally, they failed to acknowledge the fact that family members can stop the organ donation process at any time, even though the patient has signed an organ donor card. Similar results were obtained in a study with medical students in Puerto Rico (Marqués-Lespier et al., 2013). In Turkey, organ donation and transplantations are realized under the Law No. 2238 about Organ and Tissue Procurement, Preservation, Grafting and Transplantation which came into effect in 1979 $(\mathrm{MoH}, 2015)$. According to this law, organs can be taken from dead people if he or she has signed a donor card, but hospitals must take a formal written consent and approval from the family for the organ procurement.

As far as gender differences were concerned, knowledge levels regarding organ donation and transplantation were significantly higher in females than males. However, despite the significant differences were in favor of female participants, both groups generally had a low level of knowledge about organ donation and transplantation. The results revealed that female pre-service teachers were more successful in understanding that patients can receive organ transplant from living donors, and that donors do not need to take anti-rejection drugs after a transplantation operation for the rest of their lives. They were more informed about the survival years after a transplant operation, and common causes of kidney transplantation. The female pre-service teachers were also more aware that patients could receive organ transplant from living donors, and acknowledged the right of the family members to halt the donation process at any time despite the patient has signed a donor card. These results suggest that female participants were more open to receive formal and informal information about this issue. Similar to this interpretation, Mohs and Hübner (2013) states that organ donation is an altruistic helping behavior that contributes to the well-being of others, and it is therefore more congruent with the female gender role.

There were several limitations of this study. The main limitation was that the participants 
chosen through purposive sampling, who attend two universities in Turkey. Therefore, their knowledge and experiences may not be strictly representative of all Turkish pre-service science teachers. The possibility of taking answers from others and giving the desired responses during the administration of the questionnaires were other important limitations. Although, it was clearly explained that no grade would be assigned and that everyone should answer the items by themselves, it cannot be ruled out that answers had been copied from the peers. Also, the questionnaire items related to their practices and behavior might be involuntarily answered. Therefore, the results of the study should be interpreted with caution, and not be overestimated. Finally, results from such a questionnaire survey may be limited, as in-depth knowledge, practices and behaviors about organ donation and transplantation cannot be investigated. A mixed method approach is therefore recommended to further examine pre-service science teachers' knowledge, practices, behaviors and attitudes. Despite these limitations, this study provides insight into the factors associated with knowledge, practices and behavior about organ donation and transplantation among Turkish pre-service science teachers.

\section{Conclusion and Recommendations}

The pre-service science teachers overwhelmingly supported organ donation regardless of their year of study. Nevertheless, only a very small proportion of them indicated that they were registered to be an organ donor, which might be related to their personal beliefs, attitudes and lack of relevant knowledge concerning donation and transplantation procedures. On the other hand, first-year pre-service teachers were significantly more willing to donate their own organs than their fourth-year counterparts, which can be interpreted in terms of openness to the idea of organ donation and not confusion with the informal knowledge sources around them. Furthermore, significant difference were found between both groups in terms of knowing where to register to be an organ donor.

An important degree of ignorance of pre-service science teachers were determined regarding fundamental aspects of organ donation and transplantation with respect to gender and year of study. There were not significant differences between the knowledge levels of first-years and fourth-years. However, fourth-years differed significantly from their first-year counterparts in some knowledge aspects of organ donation and transplantation. Nevertheless, both groups, regardless of their year of study, had a low level of knowledge of organ donation and transplantation. Unsurprisingly, significant differences were also determined in favor of female pre-service science teachers, which might be resulted from their more empathetic character than men. However, both male and female groups displayed lower levels of knowledge about organ donation and transplantation.

In summary, to the best of our knowledge this is the first study to report the findings about the knowledge, practices and behavior of Turkish pre-service science teachers regarding organ donation and transplantation issue. The study data showed that there were significant limitations in the knowledge of pre-service science teachers about this subject. As it was mentioned before, that they do not take any regular course about organ donation and 
transplantation during their undergraduate education. However, when they graduate they will be obliged to teach the primary science curriculum, which also includes teaching of organ donation and transplantation. Based on the results of this study, we recommend that to provide pre-service science teachers with the correct information about organ donation and transplantation, a must course should be designed and included in the current Turkish science teacher education curriculum. Since Turkish universities are campus-based, this course can be given preferentially by health professionals specialized in this issue.

\section{References}

Abouna, G. M. (2008). Organ shortage crisis: problems and possible solutions. Paper presented at the Transplantation proceedings. http://dx.doi.org/10.1016/j.transproceed.2007.11.067

Alashek, W. A., Ehtuish, E. F., Elhabashi, A., Emberish, W., \& Mishra, A. (2009). Reasons for unwillingness of Libyans to donate organs after death. Libyan Journal of Medicine, 4(3), 110-113. http://dx.doi.org/10.4176/090405

Azman, N. (2013). Choosing teaching as a career: Perspectives of male and female Malaysian student teachers in training. European Journal of Teacher Education, 36(1), 113-130. http://dx.doi.org/0.1080/02619768.2012.678483

Balyer, A., \& Özcan, K. (2014). Choosing teaching profession as a career: Students' reasons. International Education Studies, 7(5), 104-115. http://dx.doi.org/10.5539/ies.v7n5p104

Berrin, O., \& Demirelli, O. (2008). The public attitudes towards organ donation in Konya. Turkiye Klinikleri Journal of Medical Ethics, Law and History, 16(3), 148-158.

Cardenas, V., Thornton, J. D., Wong, K. A., Spigner, C., \& Allen, M. D. (2010). Effects of classroom education on knowledge and attitudes regarding organ donation in ethnically diverse urban high schools. Clinical transplantation, 24(6), 784-793. http://dx.doi.org/10.1111/j.1399-0012.2009.01200.x

Chen, J. X., Zhang, T. M., Lim, F. L., Wu, H. C., Lei, T. F., Yeong, P. K., \& Xia, S. J. (2006). Current knowledge and attitudes about organ donation and transplantation among Chinese university students. Paper presented at the Transplantation proceedings. http://dx.doi.org/ 0.1016/j.transproceed.2006.08.140

Çakır, M, İrez, S., \& Doğan, Ö. K. (2010). Understandings of current environmental issues: Turkish case study in six teacher education colleges. Educational Studies, 36(1), 21-33.

Doğan, P., Toprak, D., Sunal, N., \& Doğan, İ. (2012). Knowledge, attitude and behaviors of university students on organ transplantation. Smyrna Tip Dergisi, 16-25.

Elmas, R., Öztürk, N., Irmak, M., \& Cobern, W. W. (2014). An investigation of teacher response to national science curriculum reforms in Turkey. Eurasian Journal of Physics and Chemistry Education, 6(1), 2-33. 
Etheredge, H. R., Turner, R. E., \& Kahn, D. (2014). Attitudes to organ donation among some urban South African populations remain unchanged: A cross-sectional study (1993-2013). SAMJ: South African Medical Journal, 104(2), 133-137. http://dx.doi.org/10.7196/samj.7519

Goodarzi, P., Aghayan, H. R., Larijani, B., Rafiee, A. B., Falahzadeh, K., Sahebjam, M., Ghader, F., Arjmand, B. (2015). Tissue and organ donation and transplantation in Iran. Cell and Tissue Banking, 16(2), 295-301. http://dx.doi.org/10.1007/s10561-014-9473-6

THEC, Turkish Higher Education Council. (2006). Turkish primary science teacher education $\begin{array}{lllll}\text { curriculum. } & \text { Retrieved } & \text { August } & \text { 14, from }\end{array}$ http://www.yok.gov.tr/documents/10279/49665/fen_bilgisi/f385bc78-22df-497d-bfca-7a ee $80 \mathrm{c} 75 \mathrm{c} 22$

Johnson, B., \& Christensen, L. (2013). Educational research: Quantitative, qualitative, and mixed approaches (Fifth ed.): Sage Publications, Inc.

Jung, H. (2013). Reluctance to donate organs: a survey among medical students. Paper presented at the Transplantation proceedings. http://dx.doi.org/10.1016/j.transproceed.2013.02.037

Katsari, V., Domeyer, P. J., Sarafis, P., \& Souliotis, K. (2015). Giving your last gift: A Study of the knowledge, attitude and information of Greek students regarding organ donation. Annals of Transplantation, 20, 373-380. http://dx.doi.org/10.12659/AOT.894510.

Köse, O. Ö., Önsüz, M. F., \& Topuzoğlu, A. (2015). Knowledge levels and attitudes about organ donation and transplantation among university students. North Clin Ist, 2(1), 19-25. http://dx.doi.org/ 10.14744/nci.2015.58070

Low, E. L., Lim, S. K., Ch'ng, A., \& Goh, K. C. (2011). Pre-service teachers' reasons for choosing teaching as a career in Singapore. Asia Pacific Journal of Education, 31(2), 195-210. http://dx.doi.org/ 10.1080/02188791.2011.567441

Marqués-Lespier, J. M., Ortiz-Vega, N. M., Sánchez, M. C., Soto-Avilés, O. E., \& Torres, E. A. (2013). Knowledge of and attitudes toward organ donation: a survey of medical students in Puerto Rico. Puerto Rico health sciences journal, 32(4), 187-193.

McGlade, D., \& Pierscionek, B. (2013). Can education alter attitudes, behaviour and knowledge about organ donation? A pretest-post-test study. BMJ open, 3(12), 1-7. http://dx.doi.org/10.1136/bmjopen-2013-003961

$\mathrm{MoH}$, Ministry of Health. (2015). Organ donation and transplantation in Turkey. Retrieved August 16 , 2015

from http://www.saglik.gov.tr/EN/belge/2-352/organ-donation-and-transplantation-in-turkey.h tml

Mohs, A., \& Hübner, G. (2013). Organ donation: the role of gender in the attitude-behavior relationship. Journal of Applied Social Psychology, 43(S1), E64-E70. http://dx.doi.org/10.1111/jasp.12042 
MoNE, Ministry of National Education. (2004). Ilköğretim fen ve teknoloji dersi (4. ve 5. sinıflar) ögretim programı [Primary schools science and technology education program for grades 4 and 5]. Ankara, Turkey.

MoNE, Ministry of National Education. (2005). Ilköğretim fen ve teknoloji dersi 6, 7 ve 8. sinıflar öğretim programı [Primary schools science and technology education program for grades 6, 7, and 8]. Ankara, Turkey.

MoNE, Ministry of National Education. (2013). Illköğretim kurumlar (ilkokullar ve ortaokullar) fen bilimleri dersi 3-8. siniflar ögretim programı [Primary instutions (primary and middle schools) science education program for grades 3-8]. Ankara, Turkey.

Morgan, S. E., Harrison, T. R., Afifi, W. A., Long, S. D., \& Stephenson, M. T. (2008). In their own words: the reasons why people will (not) sign an organ donor card. Health communication, 23(1), 23-33. http://dx.doi.org/ 10.1080/10410230701805158

Nunnally, J. C., \& Bernstein, I. H. (1994). Psychometric theory (3rd ed.). New York: McGraw-Hill.

ÖSYM, Student Selection and Placement Centre. (2015). Higher education programs and quotas guide. Retrieved August 14, 2015 from http://dokuman.osym.gov.tr/pdfdokuman/2015/OSYS/2015-OSYSKONTKILAVUZU15 072015.pdf

Perenc, L., Radochonski, M., \& Radochonski, A. (2012). Knowledge and attitudes of Polish university students toward organ donation and transplantation. Psychology, health \& medicine, 17(6), 667-673. http://dx.doi.org/ 10.1080/13548506.2012.658818

Radunz, S.., Juntermanns, B., Heuer, M., Frühauf, N. R., Paul, A., \& Kaiser, G. M. (2012). The effect of education on the attitude of medical students towards organ donation. Annals of Transplantation, 17(1), 140-144. http://dx.doi.org/ 10.12659/AOT.882648

Savaser, S, Sahiner, N. C., Dogan, Z., Caglar, S., \& Mutlu, B. (2015). The effect of nursing education on the opinion of students regarding organ donation. Int J Nurs Clin Pract, 2(124), 2. http://dx.doi.org/ 10.15344/2394-4978/2015/124

Schaeffner, E. S., Windisch, W., Freidel, K., Breitenfeldt, K., \& Winkelmayer, W. C. (2004). Knowledge and attitude regarding organ donation among medical students and physicians. Transplantation, 77(11), 1714-1718.

Simon, M., Chitpin, S., \& Yahya, R. (2010). Pre-service teachers' thinking about student assessment issues. International Journal of Education, 2(2). http://dx.doi.org/10.5296/ije.v2i2.490

Sperling, D., \& Gurman, G. M. (2012). Factors encouraging and inhibiting organ donation in $\begin{array}{llll}\text { Israel. Journal of bioethical inquiry, 9(4), 479-497. } & \text {. }\end{array}$ http://dx.doi.org/10.1007/s11673-012-9398-3 
Tarhan, M., Dalar, L., Yildirimoglu, H., Sayar, A., \& Altin, S. (2014). The view of religious officials on organ donation and transplantation in the Zeytinburnu district of Istanbul. Journal of Religion and Health, 1-11. http://dx.doi.org/10.1007/s10943-014-9851-1

Thornton, J. D., Wong, K. A., Cardenas, V., Curtis, J. R., Spigner, C., \& Allen, M. D. (2006). Ethnic and gender differences in willingness among high school students to donate organs. Journal of Adolescent Health, 39(2), 266-274. http://dx.doi.org/10.1016/j.jadohealth.2005.12.028

Trompeta, J. A., Chen, J. L., Cooper, B. A., Ascher, N. L., \& Kools, S. M. (2010). Development of the organ donation and transplantation knowledge survey for use in Asian American adolescents. Paper presented at the Transplantation proceedings. http://dx.doi.org/ 10.1016/j.transproceed.2010.03.136

Türkyilmaz, S., Topbaş, M., Ulusoy, S., Kalyoncu, M., Kilic, E., \& Can, G. (2013). Attitudes and behavior regarding organ donation and transplantation on the part of religious officials in the eastern black sea region of Turkey. Paper presented at the Transplantation proceedings. http://dx.doi.org/ 10.1016/j.transproceed.2013.02.095

\section{Copyright Disclaimer}

Copyright for this article is retained by the author(s), with first publication rights granted to the journal.

This is an open-access article distributed under the terms and conditions of the Creative Commons Attribution license (http://creativecommons.org/licenses/by/3.0/). 